\title{
KARAKTERISTIK KAMABOKO DENGAN SUBSTITUSI TEPUNG UBI JALAR DAN TINTA CUMI-CUMI (Loligo sp.)
}

\author{
Hasnelly ${ }^{\star}$, Nana Sutisna Achyadi, Fera Nuraudina Fatimah \\ Department of Food Technology, Engineering Faculty, Pasundan University \\ Jalan Dr. Setiabudi No. 193, Bandung, 40153, Indonesia \\ Korespondensi*: hasnelly.sriyono@gmail.com \\ Diterima: 27 Januari 2020/ Disetujui: 16 Agustus 2020
}

Cara sitasi: Hasnelly, Achyadi NS, Fatimah FN. 2020. Karakterisasi kamaboko dengan substitusi tepung ubi jalar dan tinta cumi-cumi (Loligo sp.). Jurnal Pengolahan Hasil Perikanan Indonesia. 23(2): 333-341.

\begin{abstract}
ABSTRAK
Kamaboko merupakan olahan daging ikan yang berbentuk gel dengan tekstur kenyal dan elastis, terbuat dari campuran lumatan danging ikan atau surimi, pati, garam, dan bumbu-bumbu. Tujuan penelitian ini untuk mendapatkan perbandingan tapioka dengan tepung ubi jalar serta konsentrasi tinta cumi terbaik yang menghasilkan kamaboko dengan mutu terbaik yang dinilai secara organoleptik, kimia serta fisik. Metode penelitian ada dua tahap, diawali dengan penelitian pendahuluan yaitu menganalisis asam amino pada tinta cumi-cumi serta menentukan formulasi terbaik. Dilanjutkan dengan penelitian utama menggunakan rancangan acak kelompok (RAK) Faktorial terdiri dari 2 faktor, yaitu faktor P (perbandingan tapioka dengan tepung ubi jalar dan faktor T (konsentrasi tinta cumi-cumi). Rancangan respon terdiri dari respon organoleptik, respon kimia, respon fisik dan dilakukan respon terpilih. Hasil penelitian utama menunjukkan faktor $\mathrm{P}$ berpengaruh terhadap warna, aroma, tekstur kekenyalan, kadar air dan kadar protein. Faktor T berpengaruh terhadap warna, rasa, aroma, tekstur kekenyalan, kadar air dan kadar protein. Interaksi kedua faktor berpengaruh terhadap tekstur kekenyalan dan kadar protein. Sampel terpilih yaitu perlakuan P1T3 perbandingan tapioka dengan tepung ubi jalar (P) (1:1) dan konsentrasi tinta cumi-cumi (T) (3\%), dengan nilai rata-rata warna 4,34, aroma 4,44, rasa 4,19, tekstur kekenyalan 4,40, kadar air 54,44\%, kadar protein 14,69\%, kekerasan $4363.25 \mathrm{~g}$ force, kekenyalan 32,32\%, uji warna $\Delta \mathrm{L}^{\star}$ (Light) $+2,58, \Delta \mathrm{a}^{*}\left(+\right.$ merah/-hijau) $-2,38$ dan $\Delta \mathrm{b}^{*}$ (+kuning/-biru) $-2,28$.
\end{abstract}

Kata kunci : kamaboko, tapioka, tepung ubi jalar, tinta cumi-cumi.

\section{Characterization of Kamaboko with Sweet Potato Flour Substitution and Squid (Loligo sp.) Ink Addition}

\begin{abstract}
The purpose of this research is to determine a ratio of tapioca to sweet potato flour and the concentration of squid ink producing high quality kamaboko. The quality of kamaboko was assessed organoleptically, chemically and physically. Two-stage research method was conducted. Firstly, a preliminary research, analyzing amino acids in squid ink and determining the best formulation. Secondly, the main research using a randomized block design (RBD) consisting of 2 factors, namely factor P (comparison of tapioca with sweet potato flour and factor $\mathrm{T}$ (concentration of squid ink). The responses consisted of organoleptic response, chemical response, physical response and selected response.The $\mathrm{P}$ factor affected color, aroma, elasticity texture, water content, ash content and protein content. The $\mathrm{T}$ factor influenced color, taste, aroma, elasticity texture, water content, and protein content. The interaction of the two factors affected the elasticity and protein content. The selected sample was kamaboko made from equal weight of tapioca and sweet potato flour (P) added with 3\% squid ink. The sample had a color value of 4.34, aroma 4.44, flavor 4,19 , resilience texture 4.40 , water content $54.44 \%$, ash content $1.66 \%$, protein content $14.69 \%$, hardness 4,363.25 g force, elasticity $32.32 \%$, color test $\Delta \mathrm{L}^{\star}$ (Light) $+2.58, \Delta \mathrm{a} *$ (+ red/-green) -2.38 and $\Delta \mathrm{b}$ * (+yellow/-blue) -2.28 .
\end{abstract}

Keywords: kamaboko, sweet potato flour, squid ink, tapioca. 


\section{PENDAHULUAN}

Cumi-cumi (Loligo sp.) merupakan komoditas laut di Indonesia dengan potensi yang besar. Hasil olahan cumi-cumi umumnya seperti cumi-cumi bakar, asin kering cumicumi, hidangan seafood, dan cumi-cumi beku. Namun, dalam pengolahannya, tinta cumicumi dibuang menjadi limbah (Kurniawan 2010). Tinta cumi-cumi sering dianggap tidak bermanfaat. Hasil penelitian yang sudah ada menunjukkan tinta cumi-cumi memiliki manfaat yang banyak khususnya di bidang kesehatan. Di negara lain, misalnya Jepang, cita rasa makanan diperkuat dengan adanya penambahan tinta cumicumi (Agus et al. 2013). Tinta cumi-cumi mengandung peptidoglikan lebih tinggi yang berperan sebagai antikanker dan antitumor. Senyawa antikanker tersebut merupakan mukopolisakarida sebagai karbohidrat pada peptidoglikan (Delianis et al. 2013)

Tinta cumi-cumi mengandung protein tinggi dan asam amino. Penelitian sebelumnya menunjukkan bahwa tinta cumi-cumi mengandung 14 jenis asam amino terdiri dari 8 asam amino esensial dan 6 asam amino nonesensial (Kurniawan 2010). Tinta cumi-cumi memiliki kandungan melanin. Melanin atau pigmen hitam merupakan golongan tirosinase yang memiliki kemampuan menghambat aktivitas bakteri (Fitrial dan Khotimah 2017).

Ubi jalar dapat menjadi sumber karbohidrat utama selain padi, singkong, dan jagung. Hasil panen ubi jalar sangat melimpah akan tetapi pemanfaatannya masih tergolong rendah, untuk mengurangi kerusakan selama penyimpanan perlu ada penanganan lebih lanjut terhadap ubi jalar agar dapat meningkatkan daya guna ubi jalar, baik dari segi daya simpan maupun secara ekonomis. Karakteristik tepung ubi jalar mengandung amilosa lebih tinggi dari tapioka yang akan memengaruhi kemampuan membentuk gel. Ubi jalar mengandung lebih rendah lemak dibandingkan tapioka. Lemak dapat mengganggu gelatinisasi dengan membentuk senyawa kompleks bersama amilosa, selain itu permukaan granula pati akan mengabsorpsi lemak membetuk lapisan hidrofobik yang menghambat penyerapan air (Polnaya et al. 2015).
Kamaboko merupakan olahan daging ikan yang berbentuk gel dengan tekstur kenyal dan elastis, terbuat dari campuran lumatan danging ikan atau surimi, pati, garam, dan bumbu-bumbu (Park 2013). Produk ini serupa dengan beberapa produk olahan ikan lain, misalnya bakso ikan, otak-otak, dan pempek. Olahan kamaboko dengan menambahkan tinta cumi-cumi yang kaya asam amino serta penggunaan tepung komposit ubi jalar dan tapioka diharapkan dapat menghasilkan produk kaya akan nutrisi sehingga produk kamaboko dapat diterima konsumen dan dapat menambah keberagaman produk olahan ikan.

Penelitian ini bertujuan menentukan kombinasi/rasio ubi jalar dan tapioka serta konsentrasi tinta cumi-cumi terbaik dalam menghasikan kamaboko. Produk kamaboko yang dihasilkan merupakan produk makanan yang bergizi sekaligus mengandung manfaat bagi kesehatan.

\section{BAHAN DAN METODE Bahan dan Alat}

Produk kamaboko ini terbuat dari daging dan tinta cumi-cumi, tapioka, telur, bawang putih, bawang merah, margarin, gula, merica, dan garam dibeli dari pasar Ciroyom, dan ubi jalar varietas sukuh diperoleh dari petani di daerah Parongpong. Bahan-bahan yang digunakan untuk proses analisis yaitu, $\mathrm{Na}_{2} \mathrm{SO}_{4}$ padat anhidrat pa $99,5 \%$ (Merck), $\mathrm{HgO}$ pa99\% (Merck), selenium black pa 99\% (Merck), batu didih, garam kjedahl, $\mathrm{H}_{2} \mathrm{SO}_{4}$ pa $97 \%$ (Merck), $\mathrm{NaOH}$ (Merck), granul Zn padat (Merck), $\mathrm{NaOH}$ (Merck), indikator phenolpthalein, $\mathrm{HCl}$ (Merck) dan aquadest. Peralatan yang digunakan dalam pembuatan kamaboko yaitu food processor (Kris model HB6029KGS). Alat laboratorium yang digunakan untuk analisis kimia adalah oven (Yoshino), desikator, neraca analitik (Mettler Toledo), tanur (Thermolyne), Table Cap Centrifuge (Pyrex),

\section{Metode Penelitian}

Metode yang digunakan adalah metode eksperimental. Penelitian ini dibagi dua tahap meliputi penelitian pendahuluan dan penelitian utama. Penelitian pendahuluan 
untuk mengetahui kandungan asam amino bahan baku tinta cumi-cumi menggunakan analisis HPLC serta menentukan formulasi yang digunakan untuk penelitian utama. Penelitian utama untuk menganalisis karakteristik kamaboko dari kombinasi nisbah tapioka dengan tepung ubi jalar (p) dimana p1 (1:1), p2 (1:2), dan p3 (1:3) dan tinta cumi-cumi (t) dimana t1 $1 \%$, t2 $2 \%$, dan t3 3\% dengan perlakuan p1t1, p1t2, p1t3, p2t1, $\mathrm{p} 2 \mathrm{t} 1, \mathrm{p} 2 \mathrm{t} 3, \mathrm{p} 2 \mathrm{t} 1, \mathrm{p} 3 \mathrm{t} 2$ dan $\mathrm{p} 3 \mathrm{t} 3$ menggunakan analisis organoleptik dan analisis (kadar air, protein dan uji warna).

\section{Proses Pembuatan Kamaboko}

Kamaboko dibuat menggunakan metode dari Suzuki (1981) dimulai dari penanganan bahan baku cumi-cumi dengan memisahkan bagian bukan daging: kepala, kulit, lendir, dan isi perut cumi-cumi dari bagian tubuh cumi-cumi. Tujuan proses ini adalah untuk membersihkan daging yang digunakan atau biasa disebut edible portion serta untuk mengambil dan memisahkan kantung tinta yang digunakan dalam pembuatan produk. Seluruhbahan baku ditimbang sesuaiformulasi dan basis, daging cumi-cumi dicuci dengan air dingin $\left(5-10^{\circ} \mathrm{C}\right)$ sebanyak $2-3 \mathrm{kali}$, daging cumi-cumi direndam dengan larutan garam, ditiriskan dan ditimbang sebanyak $78,5 \%$, lalu digiling menggunakan food processor selama 1 menit dengan kecepatan rendah dan 1 menit dengan kecepatan tinggi selama proses penggilingan ditambahkan es batu untuk menjaga suhu tetap rendah, dilanjutkan proses pencampuran bahan pengisi yaitu tapioka dan tepung ubi jalar sebesar $9 \%$ sesuai perlakuan, putih telur $(2,8 \%)$, bumbu-bumbu seperti bawang merah $(1,6 \%)$, bawang putih $(2,2 \%)$, margarin $(1,1 \%)$, garam $(0,7 \%)$, gula $(0,9 \%)$, merica $(0,2 \%)$ serta tinta cumi-cumi dengan konsentrasi sesuai perlakuan $(1 \%, 2 \%$ dan 3\%). Setelah tercampur, adonan dicetak kedalam loyang stainless steel kotak $(12 \times 12 \times 5)$ , lalu dikukus dengan suhu $85^{\circ} \mathrm{C}$ dalam waktu 45 menit, lalu tempering selama kurang lebih 15 menit.

\section{Analisis Data}

Penelitian ini menggunakan rancangan acak kelompok (RAK) faktorial dalam 3 kali ulangan dengan perlakuan perbedaan kombinasi nisbah tapioka dengan tepung ubi jalar dan tinta cumi-cumi. Data hasil penelitian dianalisis menggunakan analisis ragam (ANOVA). Hasil analisis ragam yang menghasilkan pengaruh yang berbeda nyata, dilanjutkan dengan uji lanjut Duncan. Data yang diperoleh dari uji organoleptik dianalisis menggunakan statistik non parametik dengan kruskal-wallis.

\section{HASIL DAN PEMBAHASAN \\ Karakteristik Bahan Baku Produk Kamaboko \\ Asam amino tinta cumi-cumi}

Hasil pengukuran kandungan asam amino non-esensial tertinggi ialah glisina dan asam glutamat, sedangkan leusina, arginina, dan fenilalanina merupakan asam amino esensial tertinggi. histidina dan valina merupakan asam amino esensial yang jumlahnya paling rendah.

Table 1 Amino acid profile of the squid ink

\begin{tabular}{|c|c|}
\hline Amino Acid & Content (mg/kg) \\
\hline Proline & 745.70 \\
\hline Threonine ${ }^{\star}$ & 703.63 \\
\hline Histidine $^{*}$ & 598.08 \\
\hline Aspartic acid & 866.50 \\
\hline Leusine $^{\star}$ & 978.94 \\
\hline Tyrosine & 468.41 \\
\hline Arginine $^{*}$ & 928.40 \\
\hline Glycine & $1,567.87$ \\
\hline Lysine ${ }^{*}$ & 678.93 \\
\hline Valine $^{*}$ & 590.46 \\
\hline Alanine & 823.41 \\
\hline Glutamic Acid & $1,121.75$ \\
\hline Phenylalanine $^{\star}$ & 21.81 \\
\hline Isoleusine $e^{\star}$ & 98.78 \\
\hline Serine & $53.3^{6}$ \\
\hline
\end{tabular}

Hal ini sesuaidengan pernyataan Okozumi dan Fujii (2000), bahwa melanoprotein tinta cumi-cumi mengandung asam amino esensial 
yang dominan berupa fenilalanina, leusina, dan arginina. Sementara kadar asam amino non esensial yang dominan adalah asam glutamat dan glisina. Menurut Okuzumi dan Fujii (2000), perbedaan kandungan asam amino ini disebabkan karena kandungan asam amino pada masing-masing spesies tidak sama. Masing-masing spesies memiliki proses fisiologis yang berbeda. Perbedaan kandungan asam amino ini juga dapat disebabkan oleh umur, musim penangkapan serta tahapan dalam daur hidup organisme. Menurut Almatsier (2006), rendahnya salah satu jenis asam amino dapat dilengkapi dengan protein dari sumber lain yang memiliki asam amino berbeda. Beberapa macam protein dapat saling mengisi kekurangan asam amino esensial. Dua jenis protein yang terbatas dalam asam amino yang berbeda, bila dimakan secara bersamaan di dalam tubuh dapat menjadi susunan protein yang lengkap, dalam keadaan tercampur, asam amino yang berasal dari berbagai jenis protein dapat saling mengisi untuk menghasilkan protein yang dibutuhkan untuk pertumbuhan dan pemeliharaan tubuh.

\section{Penentuan formula kamaboko berbasis nisbah tepung komposit dan komposisi tinta cumi-cumi berdasarkan karakteristik}

Nisbah tepung komposit dan tinta cumicumi berpengaruh terhadap rasa dan aroma pada kamaboko, sedangkan terhadap warna, tekstur dan kekenyalan tidak berpengaruh dimana $f$ hitung $<f$ Tabel pada taraf 5\% dan taraf 1\% . Formulasi terpilih (Table 2) dengan menggunakan uji organoleptik metode hedonik dibuat, dianalisis dan dikarakterisasi pada penelitian utama.

Table 2 Organoleptic values of kamaboko

\begin{tabular}{lcc}
\hline \multicolumn{1}{c}{ Test Response } & F1 & F2 \\
\hline Color & 4.33 & 4.33 \\
Aroma & 3.50 & 4.96 \\
Taste & 3.83 & 4.60 \\
Texture Elasticity & 4.33 & 4.60 \\
Average & 3.99 & 4.62 \\
\hline Note: F1 = Formulation 1; F2 = Formulation 2
\end{tabular}

\section{Karakteristik Kamaboko Warna}

Nisbah tepung komposit dan komposisi tinta cumi-cumi berpengaruh pada warna kamaboko, namun faktor interaksi keduanya tidak memberikan pengaruh. Faktor perbandingan tapioka dengan tepung ubi jalar menunjukkan perlakuan yang berbeda nyata pada taraf $5 \%(p<0,05)$. Semakin meningkatnya perbandingan tapioka dengan tepung ubi jalar maka semakin pudar warna hitam yang dihasilkan. Bahan tapioka dengan tepung ubi jalar memiliki warna putih sehingga pada saat dicampurkan dengan tinta cumi-cumi yang berwarna hitam pada proses pencampuran mengakibatkan warna adonan berwarna pudar atau sedikit keabu-abuan.

Konsentrasitinta cumi-cumi menunjukkan masing-masing perlakuan berbeda nyata. Tinta cumi-cumi dengan komposisi berbeda berpengaruh pada warna kamaboko. Semakin tinggi konsentrasi tinta cumi-cumi akan menghasilkan produk dengan warna lebih gelap.

Pigmen melanin memberikan pigmen berwarna hitam pada tinta cumi-cumi. Pigmen warna ini akan memberikan perbedaan warna pada masing-masing perlakuan (Agus et al. 2013). Melanin yang terkandung pada tinta cumi mengandung zat besi tinggi yang membantu penderita anemia. Zat besi penting untuk memproduksi hemoglobin dan myoglobin, dua protein yang ada pada sel darah merah untuk membantu distribusi oksigen dalam tubuh (Lei et al. 2008). Perlakuan dengan penambahan tinta cumi sebanyak 3\% menghasilkan produk dengan warna paling gelap.

\section{Aroma}

Faktor nisbah tepung komposit dan komposisi tinta cumi-cumi berpengaruh pada aroma produk $(p<0,05)$, sedangkan faktor interaksi keduanya tidak berpengaruh terhadap atribut aroma kamaboko $(p>0,05)$. Faktor nisbah tapioka dengan tepung ubi jalar menunjukkan bahwa nisbah tapioka dan ubi jalar 1:1 berbeda nyata pada taraf 5\% dengan perlakuan 1:3 namun tidak berbeda nyata pada taraf 5\% dengan 1:2. Nilai aroma yang dihasilkan dengan penambahan perbandingan 
tapioka dengan tepung ubi jalar yang berbeda berkisar antara 4,41 sampai dengan 4,77, panelis memebrikan nilai yang mendekati agak suka terhadap produk kamaboko. Hasil pengujian organoleptik menunjukkan nilai yang statis, tidak terdapat penurunan maupun kenaikan secara signifikan, sehingga aroma yang dihasilkan dari produk kamaboko relatif sama. Faktor konsentrasi tinta cumi-cumi menunjukkan masing-masing perlakuan berbeda nyata. Semakin meningkat konsentrasi tinta cumi-cumi akan membuat nilai organoleptik aroma kamaboko yang dihasilkan semakin tinggi. Rustianti (2008) menyatakan bahwa aroma gurih yang berlebih semakin tercium karena terbentuknya citarasa akibat perubahan struktur lemak, protein, dan karbohidrat selama proses pengolahan, sehingga tercium aroma khas yang kuat. Selama proses pemasakkan akan terbentuk berbagai komponen volatil akibat degradasi komponen bahan pangan oleh panas yang menghasilkan aroma produk yang khas (Muchtadi 2009). Aroma yang dihasilkan pada produk diduga berasal dari bumbu-bumbu yang digunakan pada pembuatan produk kamaboko ini.

\section{Rasa}

Faktor komposisi tinta cumi-cumi berpengaruh terhadap rasa, sedangkan faktor nisbah tepung komposit dan interaksi keduanya tidak memberikan pengaruh terhadap atribut rasa kamaboko. Faktor komposisi tinta cumi-cumi menunjukkan masing-masing perlakuan berbeda nyata pada taraf 5\% $(p<0,05)$. Variasi komposisi tinta cumi-cumi yang berbeda pada produk kamaboko menghasilkan produk yang cenderung memiliki tingkat kesukaan oleh panelis dalam atribut rasa yang berbeda. Penambahan konsentrasi pada perlakuan yang berbeda mengakibatkan semakin tinggi konsentrasi tinta cumi-cumi yang diberikan maka rasa asin pada kamaboko semakin kuat. Asam glutamat dan asam aspartat merupakan melanoprotein dominan pada tinta cumi-cumi yang dapat memberikan rasa umami (Agus et al. 2013). Tingginya konsentrasi tinta cumicumi membuat kamaboko yang dihasilkan terasa lebih gurih alami dibandingkan produk kamaboko pada umumnya. Okozumi dan
Fuji (2000) melaporkan bahwa melanoprotein tinta cumi-cumi mengandung asam amino non-esensial yang dominan yaitu asam glutamat dan asam aspartat. Asam glutamat dan asam aspartat ini dapat menimbulkan rasa yang gurih (umami) pada makanan (Winarno 1997).

\section{Tekstur kekenyalan}

Faktor nisbah tepung komposit dan komposisi tinta cumi-cumi serta faktor interaksi keduanya berpengaruh terhadap atribut tekstur kekenyalan $(p<0,05)$ sehingga diuji lanjut Duncan (Table 3). Nilai tekstur kekenyalan secara organoleptik tertinggi yang disukai panelis ada pada nisbah tepung komposit 1:2 dan komposisi tinta cumi-cumi 3\%. Lawrie (1999) menjelaskan bahwa tekstur kenyal terbentuk ketika proses pemanasan, protein dapat menyerap air lalu mengembang membentuk suatu matriks. Jaring-jaring mikrokristal pati ini terbentuk akibat proses gelatinisasi yang terjadi pada saat proses pemanasan dan membentuk ikatan antara molekul amilosa dengan cabang amilopektin kemudian terjadi penggabungan butir-butir pati yang membengkak membentuk semacam jaring-jaring mikrokristal yang mengendap.

\section{Kadar protein}

Interaksi faktor nisbah tepung komposit dan komposisi tinta cumi-cumi berpengaruh pada kadar protein kamaboko $(p<0,05)$ (Table 4). Kandungan protein tertinggi $15,15 \%$ diperoleh dari perlakuan nisbah tepung komposit 1:3 dan komposisi tinta cumi-cumi $1 \%$, dan kandungan protein terendah 9,95\% dari perlakuan nisbah tepung komposit 1:1 dan komposisi tinta cumi-cumi $2 \%$.

Hasil analisis kadar protein pada produk kamaboko menunjukkan bahwa dengan semakin tingginya perbandingan tapioka dengan tepung ubi jalar maka kadar protein pada produk semakin meningkat. Tapioka memiliki kadar protein 0,5\% dalam 100 gram bahan (Murdiati et al. 2015). Kandungan protein tepung ubi jalar putih 3,9\% dalam 100 gram bahan (Prasetya 2011). Kandungan protein yang dimiliki tepung ubi jalar putih berpengaruh terhadap peningkatan kadar protein pada produk kamaboko. 
Table 3 Influence of the interaction of composite flour ratio and the concentration of squid ink to the Kamaboko texture

\begin{tabular}{rccc}
\hline \multirow{2}{*}{$\begin{array}{c}\text { Composite } \\
\text { Flour Ratio }\end{array}$} & \multicolumn{3}{c}{ Squid Ink Composition (\%) } \\
\cline { 2 - 4 } & 1 & 2 & 3 \\
\hline $1: 1$ & $4.21 \mathrm{Ca}$ & $4.27 \mathrm{Aa}$ & $4.70 \mathrm{Ab}$ \\
$1: 2$ & $3.39 \mathrm{Aa}$ & $4.48 \mathrm{Bb}$ & $4.72 \mathrm{Ac}$ \\
$1: 3$ & $4.18 \mathrm{Ba}$ & $4.46 \mathrm{Bb}$ & $4.73 \mathrm{Ab}$ \\
\hline
\end{tabular}

Table 4 Influence of the interaction of composite flour ratio and the concentration of squid ink to the Kamaboko protein levels

\begin{tabular}{rrrr}
\hline \multirow{2}{*}{$\begin{array}{r}\text { Composite } \\
\text { Flour Ratio }\end{array}$} & \multicolumn{3}{c}{ Squid Ink Composition (\%) } \\
\cline { 2 - 4 } & \multicolumn{1}{c}{1} & \multicolumn{1}{c}{2} & 3 \\
\hline $1: 1$ & $14.24 \mathrm{Ab}$ & $9.95 \mathrm{Aa}$ & $14.69 \mathrm{Bb}$ \\
$1: 2$ & $12.82 \mathrm{Aa}$ & $11.63 \mathrm{ABa}$ & $10.87 \mathrm{Aa}$ \\
$1: 3$ & $15.15 \mathrm{Aa}$ & $13.93 \mathrm{Bab}$ & $11.94 \mathrm{Aa}$ \\
\hline
\end{tabular}

Faktor tinta cumi-cumi, jika dilihat dari data hasil analisis kadar protein pada produk kamaboko, menunjukkan bahwa komposisi tinta cumi-cumi yang berbeda mengakibatkan kadar protein produk kamaboko yang berbeda pula. Protein sarkoplasma sebagian besar akan larut dan terbuang pada proses pencucian. Sisa protein sarkoplasma akan terbuang dan sebagian kecil miosin, aktin, troponin, dan tropomiosin juga ikut terbuang pada pencucian berikutnya (Park 2013). Kandungan protein tertinggi terletak pada perlakukan nisbah tepung komposit 1:1 dan komposisi tinta cumi-cumi 3\%.

\section{Kadar air}

Faktor nisbah tepung komposit dan komposisi tinta cumi-cumi berpengaruh pada kadar air kamaboko $(p<0,05)$, namun interaksi kedua faktor tidak berpengaruh $(p>0,05)$. Perlakuan nisbah tepung komposit 1:1 berbeda nyata dengan perlakuan 1:2 dan $1: 3$, namun perlakuan 1:2 tidak berbeda nyata dengan perlakuan 1:3. Penurunan kadar air disebabkan karena adanya kemampuan pati dalam menyerap air. Bila suatu granula pati ditambahkan air dalam jumlah berlebih, maka granula pati tersebut akan bertambah volumenya karena terjadi penyerapan air (Palguna et al. 2013). Daya serap air granula pati dipengaruhi oleh rasio amilosa dan amilopektinnya. Pati tersusun atas amilosa dan amilopektin yang memiliki gugus hidroksil. Jumlah gugus hidroksil yang tinggi menyebabkan kemampuan menyerap air yang tinggi. Kelarutan dan derajat gelatinisasi pada pati dapat dipegaruhi oleh kandungan amilosa dan amilopektin yang dikandungnya. Suhu gelatinisasi tapioka sekitar $69^{\circ} \mathrm{C}$ hingga $87^{\circ} \mathrm{C}$ sedangkan tepung ubi jalar sekitar $79,5^{\circ} \mathrm{C}$ hingga $88,5^{\circ} \mathrm{C}$ (Polnaya et al. 2015). Granula pati akan mengalami pengembangan secara irreversible saat dipanaskan, jika panas diteruskan sampai mencapai suhu gelatinisasi, pati menyerap banyak air dan secara dramatis meningkatkan viskositas. Granula pati terus menyerap air dan mengembang sampai batas maksimal gel matriks (Park 2013).

Perlakuan nisbah tepung komposit 1:1 berbeda nyata dengan perlakuan 1:2 dan 1:3. Kadar air kamaboko dapat dipengaruhi oleh komposisi tinta cumi-cumi. Konsentrasi tinta cumi-cumi yang tinggi akan mengakibatkan kadar air kamaboko rendah. Kadar air yang semakin rendah diduga karena adanya protein pada tinta cumi-cumi yang memiliki fungsi mengikat air. Mineral pada tinta cumi-cumi dapat mengikat air bahan dan menyebabkan kadar air menurun. Kandungan mineral bahan baku yang tinggi akan memengaruhi 
kandungan mineral produk akhir (Vioni et al. 2018). Perlakuan komposisi tinta cumi-cumi $3 \%$ mengandung kadar air paling rendah $54,44 \%$. Protein pada bahan memiliki dua fungsi: melapisi atau mengemulsi lemak dan mengikat air. Jika keduanya tidak terpenuhi, kamaboko tidak akan stabil dan pecah selama pemasakan.

\section{Perlakuan terbaik}

Berdasarkan hasil analisis organoleptik dan kimia diperoleh perlakuan terbaik kamaboko dengan nisbah tepung komposit 1:1 dan komposisi tinta cumi-cumi 3\% (p1t3). Mutu kamaboko dilihat berdasarkan penilaian panelis terhadap berbagai atribut pada karakteristik kamaboko serta berdasarkan kandungan protein serta kadar airnya. Perlakuan terbaik ini selanjutnya dianalisis kembali yaitu karakteristik fisik tekstur menggunakan texture analyzer, intensitas warna menggunakan colory meter, dan analisis kimia asam amino.

\section{Respons fisik produk terbaik}

Hasil karakterisasi didapatkan kekerasan kamaboko $4363.25 \mathrm{~g}$ force dan kekenyalannya $32,32 \%$. Tingkat kekerasan memiliki nilai 0-5000 g force. Nilai kekerasan dan kekenyalan produk kamaboko tinggi. Kekerasan merupakan puncak maksimum pada gigitan pertama (Indiarto et al.2012). Nilai Springiness pada perlakuan tapioka $4 \%$ menunjukkan hasil yang tinggi sekitar 23,09\%, sedangkan nilai Springiness pada perlakuan tapioka 6\% menunjukkan hasil yang terendah sekitar $21,13 \%$. Waktu pemulihan yang dibutuhkan antara gigitan satu dan gigitan lainnya disebut elastisitas (Indiarto et al. 2012). Tepung komposit pada kamaboko memberikan sifat kenyal. Penelitian mengenai pembuatan kamaboko berbahan baku ikan kurisi dengan penambahan karagenan menghasilkan produk dengan kisaran gel strength antara 1679,782872,62 $\mathrm{g} / \mathrm{cm}^{2}$ (Agustin 2012).

Kekenyalan kamaboko diakibatkan oleh gelatinisasi pati yang terkandung pada tepung ubi jalar dan tapioka. Tepung ubi jalar yang dibuat dengan suhu pengeringan $60^{\circ} \mathrm{C}$ akan menghasilkan nilai swelling power yang tinggi karena sebagian pati sudah tergelatinisasi dan memiliki daya serap air yang besar (Anwar dan Kemalawaty 2019). Tekstur kamaboko yang kenyal menandai bahwa nisbah tapioka dan tepung ubi jalar 1:1 dapat digunakan sebagai bahan pengisi produk olahan pangan.

Intensitas warna pada produk terbaik

Uji warna produk kamaboko didapatkan $\Delta \mathrm{L}^{*}$ (Light) $+2,58, \Delta \mathrm{a}^{*}(+$ merah $/-$ hijau $)$ -2,38, dan $\Delta \mathrm{b}^{\star}$ (+ kuning/- biru) -2,28. Warna produk cenderung tua dengan nilai $L^{*}$ yang menunjukkan sifat terang relatif kecil hanya $+2,58$. Nilai tersebut dipengaruhi juga oleh nilai $\mathrm{a}^{*}$ yang cenderung mendekati warna hijau tua karena nilainya sendiri negatif $-2,38$ dan nilai $b^{*}$ yang cenderung mendekati warna biru tua karena nilainya sendiri negatif $-2,28$. Penelitian serupa mengenai pembuatan kamaboko berbahan dasar ikan kurisi menghasilkan produk yang lebih cerah dengan nilai derajat putih rata-rata sebesar 53,21 hingga 73,78 (Agustin 2012).

Warna yang dihasilkan pada produk kamaboko disebabkan adanya pigmen melanin pada tinta cumi-cumi. Tingginya

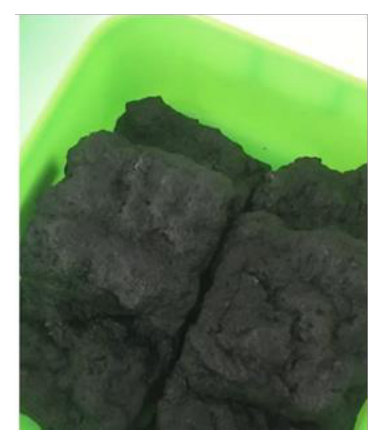

Figure 1 Kamaboko Squid Ink 
komposisi tinta cumi-cumi yang ditambahkan menurunkan kecerahan warna dari produk (Agus et al. 2013). Komposisi tinta cumi-cumi sebanyak 3\% menurunkan kecerahan warna kamaboko yang dihasilkan, sehingga warna produk menjadi lebih gelap dibandingkan produk kamaboko pada umumnya.

\section{Asam amino pada produk terbaik}

Asam amino yang terkandung dalam hasil hidrolisat protein kamaboko yaitu 8 jenis asam amino esensial dan 7 jenis asam amino non-esensial (Table 5).

Table 5 Amino acid profile of kamaboko product

\begin{tabular}{|c|c|}
\hline Amino Acid & Content (mg/kg) \\
\hline Aspartic acid & $6,621.15$ \\
\hline Leusine ${ }^{*}$ & $8,004.69$ \\
\hline Tyrosine & $2,250.21$ \\
\hline Proline & $2,990.95$ \\
\hline Threonine $^{*}$ & $4,325.07$ \\
\hline Valine $^{*}$ & $4,266.04$ \\
\hline Alanine & $4,713.06$ \\
\hline Serine & $4,042.55$ \\
\hline Glutamic Acid & $12,112.76$ \\
\hline Phenylalanine ${ }^{\star}$ & $4,342.59$ \\
\hline Isoleusine $e^{\star}$ & $4,618.08$ \\
\hline Histidine $^{*}$ & $1,949.61$ \\
\hline Arginine $^{*}$ & $7,083.93$ \\
\hline Glisine & $4,876.13$ \\
\hline $\operatorname{Lisin}^{*}$ & $5,895.11$ \\
\hline
\end{tabular}

Produk dengan penambahan tinta cumicumi, seperti kamaboko yang telah diteliti, dapat memberikan manfaat yang sangat penting bagi tubuh. Selain dari nilai gizinya yang tinggi, kelebihan lain penggunaan tinta cumi-cumi untuk meningkatkan nilai ekonomis dari tinta cumi-cumi, meningkatkan keragaman produk pangan (diversifikasi pangan), dan menhasilkan mutu produk yang dapat diterima oleh konsumen.

\section{KESIMPULAN}

Kamaboko terbaik dari kombinasi nisbah tapioka dengan tepung ubi jalar dan substitusi tinta cumi-cumi berdasarkan karakteristik fisik, kimia, dan organoleptik adalah perlakuan P1T3 perbandingan tapioka dengan tepung ubi jalar $(\mathrm{P})$ (1:1) dan konsentrasi tinta cumi-cumi (T) (3\%). Karakteristik nilai fisik dan kimia perlakuan p1t3 mendekati standar produk kamaboko komersial di industri Indonesia.

\section{DAFTAR PUSTAKA}

Agus S, Agusandi, Dwita LS. 2013. Pengaruh penambahan tinta cumi-cumi terhadap kualitas nutrisi dan penerimaan sensoris mi basah. Fishtech. II:22-37.

Agustin TI.2012. Mutu fisik dan mikrostruktur kamaboko ikan kurisi (Nemipterus nematophorus) dengan penambahan karaginan. Jurnal Pengolahan Hasil Perikanan. 15(1):17-26.

Anwar C, Kemalawaty M. 2019. Physicochemical properties of sweet potato starches by studying their varieties and drying temperatures. Jurnal Teknologi Pertanian. 20(1):33-44.

Delianis P, Agung SA, Sri S. 2013. Karakterisasi tinta cumi-cumi (Sepiothus lessoniana) Dan. Prosiding Pertemuan Ilmiah Nasional Tahunan X ISOI 2012 244-53.

Indiarto, Rossi, Nurhadi B, Subroto E. 2012. Kajian karakteristik tekstur dan organoleptik daging ayam asap berbasis teknologi asap cair tempurung kelapa. Jurnal Teknologi Hasil Pertanian V(2): 106-16.

Kurniawan, Lestari S, Siti HRJ. 2012. Hidrolisis protein tinta cumi-cumi (Loligo sp) dengan enzim papain. FishTech. I(01): 41-54.

Lei, Mengru, CH Xue, Yu-ming Wang, ZJ Li, Y Xue, JF Wang. 2008. Effect of Squid Ink Melanin-Fe on Iron Deficiency Anemia Remission. Vol. 73.

Murdiati A, Anggrahini S, Supriyanto, Alim A. 2015. Increased protein content of wet noodle from tapioca substituted by white jack bean. Agritech 35(3): 251-60.

Palguna I, Gusti PA, Sugiyono, Haryanto B. 2013. Optimasi rasio pati terhadap air dan 
suhu gelatinisasi untuk pembentukan pati resisten tipe III pada pati sagu. Pangan. 22(3): 253-62.

Park JW. 2013. Surimi and Surimi Seafood. Tokyo (JP): CRC Press.

Polnaya FJ, Breemer R, Gelora HA, Helen, CD Tuhumury. 2015. Karakteristik sifat-sifat fisiko-kimia pati ubi jalar, ubi kayu, keladi dan sagu. Agrinimal. 5(1): 37-42.

Prasetya HA 2011. Penggunaan tepung ubi jalar pada pembuatan kerupuk kempelang
Palembang. Jurnal Dinamika Penelitian Industri. 22(1): 1-8.

Vioni N, Liviawaty E, Rostini I, Afrianto E, Kurniawati N. 2018. Fortifikasi tinta cumi-cumi pada cup cake terhadap tingkat kesukaan. Jurnal Pengolahan Hasil Perikanan Indonesia. 21(1):78.

Yuspihana F, Khotimah IK. 2017. Aktivitas antibakteri dari melanin tinta sotong dan cumi-Cumi. Jurnal Pengolahan Hasil Perikanan Indonesia 20: 266-74. 